\title{
COMPLETE REVERSAL OF ISCHEMIC WALL MOTION ABNORMALITIES BY COMBINED USE OF GENE THERAPY WITH TRANSMYOCARDIAL LASER REVASCULARIZATION
}

Umer Sayeed-Shah, MD

Michael J. Mann, MD

Jeffrey Martin, MDa

Sergery Grachev, MD ${ }^{\mathrm{a}}$

Sharon Reimold, MD $^{\mathrm{b}}$

Rita Laurence, $\mathrm{BS}^{\mathrm{a}}$

Victor Dzau, MD ${ }^{\mathrm{b}}$

Lawrence H. Cohn, MD
Introduction: Transmyocardial laser revascularization is believed to induce an angiogenic response within ischemic myocardium. We evaluated transgene expression in the setting of transmyocardial laser revascularization and hypothesized that intramyocardial injection of plasmid DNA encoding the gene for vascular endothelial growth factor could enhance the revascularization achieved by transmyocardial laser revascularization, resulting in improved cardiac function. Methods: Ten Yorkshire pigs had carbon dioxide-transmyocardial laser revascularization or acupuncture sites with injections of an expression plasmid encoding the gene for $\beta$-galactosidase with or without HVJ-liposomes. Three days after transduction, transgene expression was determined by enzyme-linked immunosorbent assay. Six weeks after placement of a constrictor on the left circumflex artery, 29 pigs were randomized to ischemic controls $(n=5)$, transmyocardial laser revascularization $(n=$ 4), transmyocardial laser revascularization with expression plasmid $\beta$ galactosidase injections $(n=5)$, expression plasmid-vascular endothelial growth factor injections $(n=4)$, or transmyocardial laser revascularization with expression plasmid-vascular endothelial growth factor $(n=5)$ and harvested 6 weeks after therapy. Six transmyocardial laser revascularization pigs had either expression plasmid $\beta$-galactosidase or expression plasmid-vascular endothelial growth factor injections and were harvested at 2 weeks. Normal pigs $(n=5)$ were included for comparison. Left ventricular free wall motion was assessed by a cardiologist in a blinded manner. Results: Transgene expression did not vary significantly with or without HVJ-liposomes in transfected transmyocardial laser revascularization myocardium. However, expression was detected in 56 of $60(93 \%)$ transmyocardial laser revascularization-transfected sites, but in only 10 of $20(50 \%)$ non-transmyocardial laser revascularization sites $(P<.001)$. All ( 5 of 5 hearts) of the transmyocardial laser revascularization-vascular endothelial growth factor treated hearts displayed no evidence of wall motion abnormalities. Only these hearts had a statistically significantly different rate of wall motion abnormality compared with ischemic controls $(P=.004)$. Conclusion: Transfection efficiency was improved with the use of transmyocardial laser revascularization. Wall motion abnormalities were completely reversed within 6 weeks after transmyocardial laser revascularization with the direct injection of an expression plasmid encoding vascular endothelial growth factor. (J Thorac Cardiovasc Surg 1998;116:763-9)
From the Divisions of Cardiac Surgery a and Cardiovascular Medicine, ${ }^{\mathrm{b}}$ Brigham and Women's Hospital, Harvard Medical School, Boston.

Read at the Seventy-eighth Annual Meeting of The American Association for Thoracic Surgery, Boston, Mass, May 3-6, 1998.

Received for publication April 9, 1998; revisions requested June 8,
1998; revisions received July 1, 1998; accepted for publication July 1, 1998.

Address for reprints: Lawrence H. Cohn, MD, Chief of Cardiac Surgery, Brigham and Women's Hospital, 75 Francis St, Boston, MA 02115.

Copyright $@ 1998$ by Mosby, Inc.

$0022-5223 / 98 \$ 5.00+0 \quad \mathbf{1 2 / 6 / 9 2 8 1 1}$ 
T he morbidity and mortality of ischemic heart disease are directly attributable to an imbalance between the heart's oxygen delivery and consumption. Transmyocardial laser revascularization (TMR) with a high-energy carbon dioxide laser that creates channels through the myocardial wall has recently been studied in patients not amenable to conventional revascularization procedures, resulting in symptomatic improvement. ${ }^{1}$ However, there is mounting evidence that these channels do not remain patent and that neovascularization has been imputed to explain the observed therapeutic effects of TMR. ${ }^{2,3}$

The delivery of pro-angiogenic factors may enhance this neovascularization, and direct gene transfer may provide a means for effective delivery of such factors to the target myocardium. Vascular endothelial growth factor (VEGF), a 46-kd dimeric protein, has been shown to promote new vessel formation in both normally perfused and ischemic tissues. ${ }^{4,5}$ Previous attempts at viral-mediated gene transfer in the setting of TMR have been associated with a significant inflammatory response with no evidence of enhanced transgene expression. ${ }^{6}$ However, various forms of cellular stress have been shown to enhance gene expression in vitro. It has been established that in vivo direct gene transfer with "naked" plasmid DNA (ie, DNA not associated with the use of viral or viral-conjugate vectors) is feasible in myocardial tissue, though transgene expression occurs at low levels. ${ }^{7}$ We sought to define the transduction capability of cells in this zone of injury after TMR by quantifying the degree and the efficiency of myocardial transgene expression with the use of non-live viral vectors. The reporter gene $\beta$-galactosidase in the form of either an expression plasmid or incorporated in fusigenic hemagglutinating virus of Japan (HVJ)-liposome complexes was used in the setting of TMR with a high-energy carbon dioxide laser in porcine myocardium. In addition, we hypothesized that direct myocardial injection of plasmid DNA encoding the gene for $\mathrm{VEGF}_{165}$ could enhance the revascularization achieved by TMR in chronically ischemic porcine hearts, resulting in improved cardiac function.

\section{Materials and methods}

\section{Myocardial transfection studies}

Left minithoracotomy. Ten Yorkshire pigs were premedicated with ketamine $(10 \mathrm{mg} / \mathrm{kg})$, intubated, and maintained with general inhalational anesthesia with $2 \%$ isofluorane. Cefazolin $(40 \mathrm{mg} / \mathrm{kg}), \mathrm{MgSO}_{4}(40 \mathrm{mg} / \mathrm{kg})$, and bretylium tosylate $(10 \mathrm{mg} / \mathrm{kg})$ were given intravenously as prophylaxis against wound infection and atrial and ventricular arrhythmias. A left anterior minithoracotomy was performed through the fourth intercostal space, and the pericardium was incised and suspended to reveal the free wall of the left ventricle.
Transesophageal echocardiogram. A transesophageal ultrasonic probe was placed to visualize the left ventricular wall motion and to confirm placement of transmural channels by the carbon dioxide laser.

$T M R$. An 800-watt carbon dioxide laser was used to produce transmural channels discharging $16 \mathrm{~J}$ over a pulse width of $20 \mathrm{~ms}^{1-3}$ The channel density was approximately 1 chan$\mathrm{nel} / \mathrm{cm}^{2}$ on the left ventricular free wall, being careful to avoid the coronary vasculature. TMR areas were marked by a 5-0 polypropylene stitch.

Gene delivery. Three equidistant $100 \mu \mathrm{L}$ intramyocardial injections were placed with a 25-gauge needle within $4 \mathrm{~mm}$ of the TMR sites. Two vehicles, either fusigenic HVJ-liposomes or naked plasmid were used to deliver an expression plasmid (pSV) containing the gene encoding $\beta$-galactosidase with an SV40 early promotor and enhancer. This promotor has been determined to be similarly effective in driving transgene expression in both ischemic and nonischemic myocardium. ${ }^{7,8}$ Two doses of DNA each were used for myocardial transfection: 5 and $15 \mu \mathrm{g}$ for HVJ-liposomes and 100 and 200 $\mu \mathrm{g}$ for naked plasmid. Similar injections were placed around 22-gauge needle-puncture sites of non-TMR myocardium. The protocol used for HVJ-liposome preparation has been well described. ${ }^{9}$ A PGL2 expression plasmid, using an SV40 early promotor and enhancer, but encoding the gene for firefly luciferase, was injected at TMR sites in an identical manner for use as a control. For VEGF gene transfer experiments, a pSV expression plasmid containing the gene-encoding VEGF $_{165}\left(\mathrm{pSV} \mathrm{VEGF}_{165}\right)$ with an SV40 early promotor and enhancer was used (Fig 1).

Cardiectomy. Animals were killed 3 days after transduction. Two individual, 10-mm length, full-thickness myocardial samples were taken at 5-mm intervals from each TMR and injection site and snap frozen in liquid nitrogen. Sixty samples from TMR-transfected myocardium and 20 samples from non-TMR transfected myocardium, in addition to 20 control samples of TMR-luciferase transfected myocardium, were taken for analysis.

Analysis of $\beta$-galactosidase expression. Samples were homogenized with $0.25 \mathrm{mmol} / \mathrm{L}$ Tris- $\mathrm{C} 1, \mathrm{pH} 7.8$, containing $0.1 \mathrm{mmol} / \mathrm{L}$ phenylmethylsufonyl fluoride, and centrifuged at 7500 rmax at $4^{\circ} \mathrm{C}$ for 30 minutes. $\beta$-Galactosidase protein levels were assayed in extracts from tissue homogenates by enzyme-linked immunosorbent assay, with subtraction of background from TMR-myocardium transfected with luciferase. These samples were normalized from protein by Bradford protein assay. Data are represented in terms of picograms of $\beta$-galactosidase produced per milligram of tissue protein and expressed as mean \pm SD.

\section{Chronically ischemic hearts}

Left minithoracotomy, constrictor implantation. Forty Yorkshire pigs $(25 \mathrm{~kg})$ were premedicated with ketamine $(10$ $\mathrm{mg} / \mathrm{kg}$ ), intubated, and maintained with general inhalational anesthesia with $2 \%$ isofluorane. Cefazolin $(40 \mathrm{mg} / \mathrm{kg})$, $\mathrm{MgSO}_{4}(40 \mathrm{mg} / \mathrm{kg})$, and bretylium tosylate $(10 \mathrm{mg} / \mathrm{kg})$ were given intravenously as prophylaxis against wound infection and atrial and ventricular arrhythmias. With the use of the sterile operative technique, a left anterior minithoracotomy 


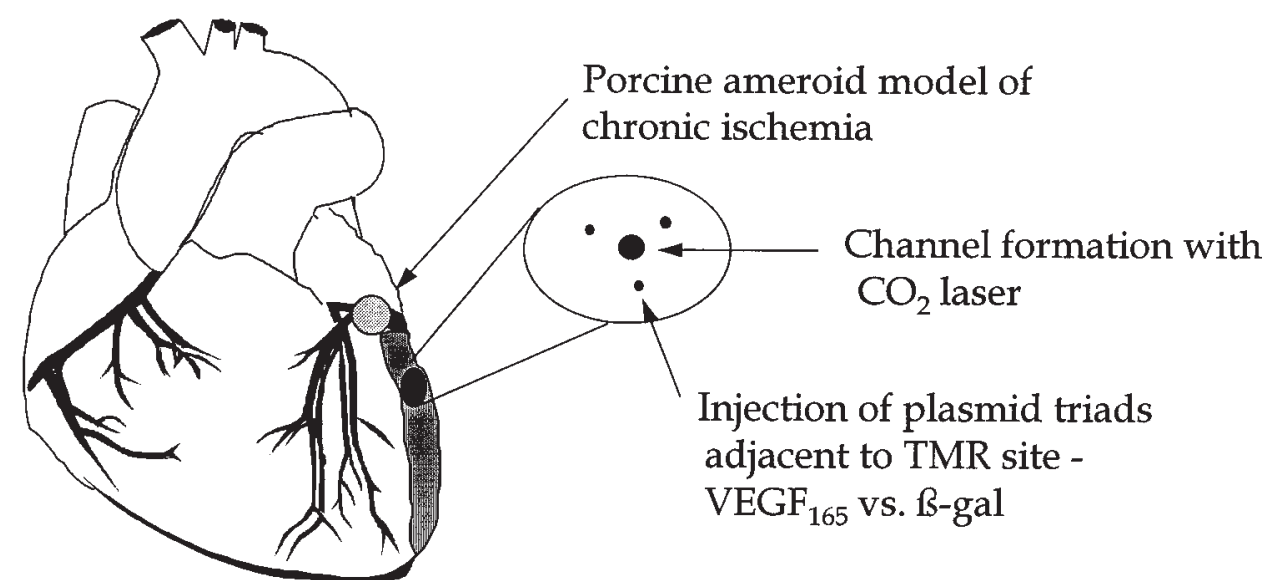

Fig 1. TMR with angiogenic gene therapy. Six weeks after ameroid constrictor placement, animals were randomized into groups I through V. Therapy was administered in the area of reversible ischemia.

was performed through the fourth intercostal space, and the pericardium was incised and suspended to reveal the free wall of the left ventricle, atrioventricular groove, and left circumflex artery. A 2.5-mm ameroid constrictor (Research Instruments and Manufacturing, Corvallis, Ore) was placed to visualize left ventricular wall motion before and after the ameroid constrictor with rapid atrial pacing (Medtronic 5375 Demand Pulse Generator, Medtronic, Inc, Minneapolis, Minn) to ensure adequate positioning of the ameroid constrictor and to document baseline left ventricular function with and without stress/rapid atrial pacing. ${ }^{3}$ The pericardium was approximated and chest wall was closed in anatomic layers. An ipsilateral transient $28 \mathrm{~F}$ tube thoracostomy that had been placed to suction was removed on extubation. Animals were allowed to recover 6 weeks to permit occlusion of the ameroid constrictor, with development of stable collateralization. Of these 40 animals, 4 pigs experienced sudden cardiac death at 14 to 17 days after ameroid constrictor implantation with microinfarcts of the left ventricular free wall or anterolateral papillary muscle at autopsy. Additionally, 2 pigs were killed because of joint effusions at 8 and 12 days after ameroid constrictor implantation. The surviving animals were randomized to the following groups (Fig 1):

Group I (ischemic controls, $\mathrm{n}=5$ ) had no further intervention.

Group II (TMR, $\mathrm{n}=4)$ underwent TMR in the area at risk at 6 weeks after ameroid constrictor implantation. A transesophageal echocardiography (TEE) probe was placed, and the ventricle rapidly paced to identify areas at risk along the left ventricular free wall. Images were digitally recorded for subsequent analysis by a cardiologist in a blinded fashion. An 800-watt carbon dioxide laser (Heart Laser; PLC Systems, Franklin, Mass) was used to produce transmural channels discharging $16 \mathrm{~J}$ over a pulse width of $20 \mathrm{~ms}$. The channel density was approximately $1 \mathrm{channel} / \mathrm{cm}^{2}$ on the left ventricular free wall, with care to avoid the coro- nary vasculature. Channels were confirmed by TEE and by pulsatile flow during systole. There were 15 to 18 TMR sites per heart, which were marked by 5-0 polypropylene stitches.

Group III (TMR-gal, $\mathrm{n}=5$ ) underwent TMR at 6 weeks with 3 equidistant intramyocardial injections of $100 \mu \mathrm{g}$ of a pSV encoding the gene for $\beta$-galactosidase (pSV- $\beta$-galactosidase) surrounding each TMR site.

Group IV (VEGF, $\mathrm{n}=4$ ) had sets of 3 equidistant injections of $100 \mu \mathrm{g}$ of an expression plasmid encoding the gene for $\mathrm{VEGF}_{165},\left(\mathrm{pSV}-\mathrm{VEGF}_{165}\right)$ without TMR at 6 weeks.

Group V (TMR-VEGF, $\mathrm{n}=5$ ) had TMR with each site surrounded by 3 injections of $100 \mu \mathrm{g}$ of $\mathrm{pSV}-\mathrm{VEGF}_{165}$ at 6 weeks. All animals were harvested at 12 weeks after ameroid constrictor placement. Six additional pigs underwent TMR with either pSV-ßgalactosidase or pSV-VEGF ${ }_{165}$ injections at 6 weeks but were harvested at 8 weeks ( 2 weeks after therapy).

Group VI $(\mathrm{n}=5)$ were age and weight-matched normal Yorkshire pigs $(45 \mathrm{~kg})$ for comparison with groups I through $\mathrm{V}$ at 12 weeks.

All animals were given humane care in compliance with the "Principles of Laboratory Animal Care" formulated by the National Society for Medical Research, and the "Guide for the Care and Use of Laboratory Animals" published by the National Institutes of Health (NIH publication 86-23, revised 1985).

Median sternotomy. Animals were killed via median sternotomy at 6 weeks after transduction and after TMR, or a total of 12 weeks after ameroid constrictor implantation. TEE and epicardial echocardiography was performed in the paced and unpaced myocardium; images were recorded and stored for analysis. Hearts were assessed for evidence of regional wall motion abnormalities and overall ventricular function in comparison with ischemic controls and age- and weightmatched pigs. 


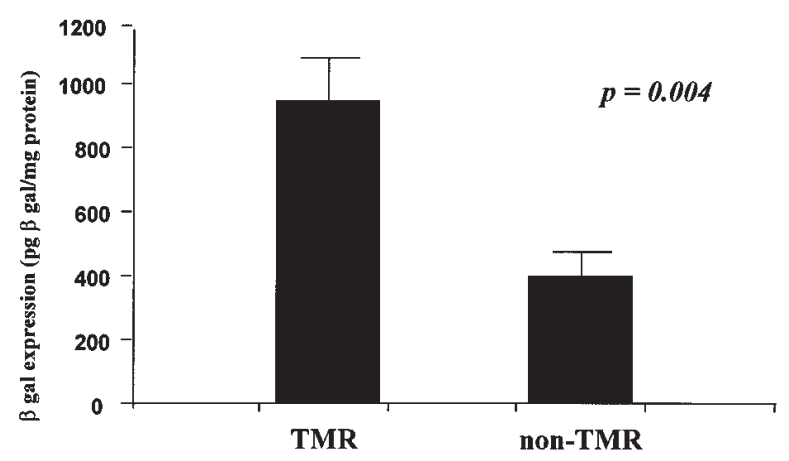

Fig 2. Transgene expression level in positively reporting sites of pSV- $\beta$-galactosidase transfected TMR and non-TMR (acupuncture) myocardium after subtraction of background from PGL2-luciferase transfected TMR myocardium. (Mean $\pm \mathrm{SD} ; P=.004$ by 2-tailed Student's $t$ test).

Statistical analysis. The data represented are expressed as mean $\pm \mathrm{SD}$. Data were analyzed by 2 -tailed Student's $t$ test and by Fisher's exact test with application of Bonferroni corrections as indicated.

\section{Results}

Transgene expression. Myocardial transgene expression was detected in 56 of 60 TMR-transfected sites 3 days after transfection (93\%) but in only 10 of 20 $(50 \%)$ non-TMR sites at the same time point $(P<.001$ by 2-tailed Fisher's exact test).

The level of transgene expression did not vary significantly among delivery methods for TMR-transfected sites at the doses tested. HVJ-liposomes yielded $992 \pm$ $146 \mathrm{pg} \beta$-galactosidase $/ \mathrm{mg}$ protein at doses of $5 \mu \mathrm{g} / 100$ $\mu \mathrm{L}$ and $1211 \pm 238 \mathrm{pg} \beta$-galactosidase/mg protein at 15 $\mu \mathrm{g} / 100 \mu \mathrm{L}$. Similarly, naked plasmid yielded $1099 \pm$ $322 \mathrm{pg} \beta$-galactosidase/mg protein at doses of 100 $\mu \mathrm{g} / 100 \mu \mathrm{L}$, and $761 \pm 179 \mathrm{pg} \beta$-galactosidase $/ \mathrm{mg}$ protein at doses of $200 \mu \mathrm{g} / 100 \mu \mathrm{L}$. However, the level of $\beta$-galactosidase expressed around TMR sites (987 \pm $228 \mathrm{pg} / \mathrm{mg}$ ) was approximately 2.4 times higher than expression in non-TMR transfected sites with positive expression $(408 \pm 148 \mathrm{pg} / \mathrm{mg}), P=.004$ by 2 -tailed Student's $t$ test (Fig 2).

Functional analysis. Left ventricular free wall motion in the area at risk was assessed by a cardiologist in a blinded fashion. Hearts were scored as normal (no regional wall motion abnormality, normal systolic function) or abnormal (hypokinetic, dyskinetic or akinetic wall motion, or impaired systolic function). There were no wall motion abnormalities either before or immediately after ameroid constrictor placement. Six weeks after treatment at harvest, all of the ameroidalone hearts had impaired wall motion ( $0 / 5$ normal), whereas 75\% (3 of 4) of the TMR, 60\% (3 of 5) of the TMR-galactosidase hearts, and $50 \%$ (2 of 4) of the VEGF hearts displayed evidence of persistent wall motion abnormalities. Two of the 3 TMR-VEGF-treated hearts evaluated at 2 weeks after therapy had completely normal wall motion, whereas all 3 of the TMR$\beta$-galactosidase-treated hearts had persistent abnormalities at the same time point. Those hearts with impaired function were generally hypokinetic in the areas at risk, with occasional areas of akinesia. There were discrete focal abnormalities in 1 of the TMRtreated hearts and 1 of VEGF-treated hearts, both of which were scored as having normal overall wall motion. In contrast, all (5 of 5) of the hearts treated with TMR-VEGF displayed no evidence of regional wall motion abnormality. Only the TMR-VEGF hearts had a statistically significantly different rate of wall motion abnormality compared with untreated ischemic hearts ( $P=.0039$ by 2-tailed Fisher's exact test).

\section{Discussion}

Direct injection of naked plasmid DNA has been most successful in achieving transgene expression in striated muscle tissue. Myocardium, in particular, displays the ability to uptake foreign DNA at low, but predictable levels of expression. ${ }^{10}$ The results of this study demonstrate that direct non-viral gene transfer at sites of TMR is feasible and that thermal injury associated with TMR enhances both the efficiency and the degree of myocardial transgene expression. Furthermore, the combined use of TMR with the direct injection of a plasmid encoding the gene for $\mathrm{VEGF}_{165}$ completely reversed ischemic wall motion abnormalities within 6 weeks after therapy in pigs that had previously undergone left circumflex artery ameroid constrictor placement.

TMR represents the latest in a series of approaches initially intended to directly revascularize ischemic myocardium. Beck ${ }^{11}$ performed a myopexy, omentopexy, and poudrage; and Vineberg ${ }^{12}$ implanted the internal thoracic artery into the myocardium for revascularization. Sen and associates ${ }^{13,14}$ introduced acupuncture as a method to produce transmural channels. Mirhoseini and Cayton ${ }^{15}$ developed the use of a lowenergy carbon dioxide laser to produce transmural channels to directly perfuse the myocardium with ventricular blood; later this was attempted with a holmium:YAG laser. Failure of these techniques to produce conclusive evidence of persistent myocardial revascularization was thought to be related to immediate tissue reapproximation after acupuncture and low laser energy levels. ${ }^{2,15}$ A higher energy 800-watt carbon dioxide laser discharging $16 \mathrm{~J}$ over a short pulse width (20 ms) has been used recently in a multicenter trial to treat 


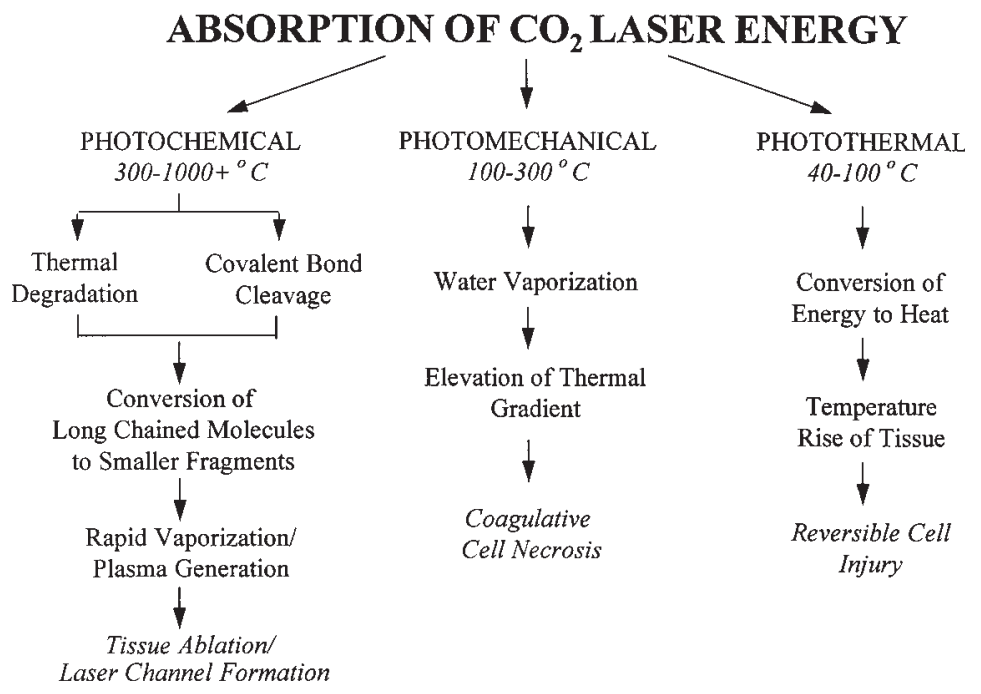

Fig 3. Pathologic effects in myocardial tissue of carbon dioxide laser application.

end-stage coronary artery disease. The patients selected had advanced coronary artery disease that was not amenable to conventional revascularization procedures, and most of the patients had undergone either coronary artery bypass grafting or percutaneous transluminal coronary angioplasty. ${ }^{1}$ Collateral blood flow was increased, and mean anginal scores were improved over the 12-month period of observation after TMR, with an operative mortality rate of $9 \%$. Studies in both human beings and animal models have revealed increased subendocardial perfusion ratios. ${ }^{1-3}$ It appears that an ongoing process of new microvessel growth and a progressive recruitment of existing collaterals may occur, stimulated by this interaction of the laser with myocardial tissue. Other mechanisms, however, may be important in the short-term symptomatic relief observed in patients. ${ }^{16}$

The chromophore for the energy discharged from a carbon dioxide laser is water. ${ }^{17,18}$ The central zone of injury has been characterized as photochemical and is surrounded by concentric photomechanical and photothermal zones of tissue injury. The photothermal zone, with gradients between $40^{\circ} \mathrm{C}$ and $100^{\circ} \mathrm{C}$, is characterized by sublethal cellular stress that may enhance plasmid uptake and subsequent gene expression ${ }^{17,18 a}$ (Fig 3). Many cells in this zone survive, and our findings of improved gene expression within this region imply that not only is gene transfer compatible with TMR but that TMR may actually improve the reliability of gene transfer and the level of target protein expression achieved by direct myocardial injection.

VEGF is synthesized by many cell types, but the restriction of VEGF receptor expression yields relative endothelial cell-specific mitogenicity. ${ }^{4,19}$ Both tissue VEGF production and endothelial receptor density are enhanced by regional ischemic insults, leaving the ischemic zone more responsive to VEGF. ${ }^{5}$ VEGF and basic FGF have been shown to improve collateral flow from angiogenesis, with subsequent enhancement of myocardial perfusion but inconsistent improvement of regional myocardial function in ischemic models. However, these previous studies have used in-dwelling catheters, methods for slow release around coronary vessels, or multiple repeated dosing to achieve significance. $^{20-23}$ The stability of the neovascularization achieved by simple angiogenic factor therapy has not been defined, nor have the risks of oncogenic transformation or stimulation of neo-intimal hyperplasia from prolonged intravascular growth factor administration been delineated for this approach. ${ }^{24,25}$ Because the "naked" plasmid is injected locally in our approach, a greater spatial restriction on plasmid-mediated transgene expression diminishes the possibility of significant uncontrolled regional or systemic exposure that exists with viral-based gene delivery systems that have been tested. ${ }^{26}$ Furthermore, plasmid-mediated gene therapy may allow a single injection of a gene encoding a proangiogenic agent to produce sustained local protein production, which could act in a paracrine fashion and obviate the need for repeated administration of the protein. ${ }^{7,27}$

The process of new blood vessel growth is complex and known to involve multiple growth factors and the up-regulated expression of multiple receptors on endothelial and other vascular cells. ${ }^{23,28}$ The simple delivery of a single factor may therefore be insufficient 
to achieve maximal therapeutic effect. TMR with its controlled local tissue injury is likely to stimulate this broader range of pro-angiogenic responses, including the local inflammation that has been shown to play a critical role in the stimulation of both capillary and larger vessel growth. ${ }^{28}$ The combination of TMR and specific growth factor over-expression may therefore be particularly synergistic. Such an effect would not be achieved by the simple injection of either a single protein or gene encoding for its production. Additionally, the progressive nature of the response of ischemic myocardium to TMR may potentially be protective in the genetically modified heart should this level of genetically induced vascularity not be stable over time. Currently, we are quantifying the degree of collateralization achieved with this combined therapy, and further studies will be required to evaluate the stability of functional improvement and to establish the long-term efficacy of genetic enhancement of myocardial tissue.

\section{REFERENCES}

1. Horvath K, Cohn LH, Cooley D, et al. Transmyocardial laser revascularization: results of a multicenter trial with transmyocardial laser revascularization used as a sole therapy for end-stage coronary artery disease. J Thorac Cardiovasc Surg 1997;113:64554.

2. Horvath K, Smith WJ, Laurence RG, et al. Recovery and viability of an acute myocardial infarct after transmyocardial laser revascularization. J Am Coll Cardiol 1995;25:258-63.

3. Zlotnick A, Ahmad RM, Reul RM, et al. Neovascularization occurs at the site of closed laser channels after transmyocardial laser revascularization. Surg Forum 1996;47:286-7.

4. Flamme I, von Reutern M, Drexler HC, et al. Overexpression of VEGF in the avian embryo induces hypervascularization and increased vascular permeability. Dev Biol 1995;171:399-414.

5. Tuder RM, Flook BE, Voelkel NF, et al. Increased gene expression for VEGF and VEGF receptors KDR/flk and flt in lungs exposed to acute and chronic ischemia. J Clin Invest 1995;95:1798-807.

6. Fleischer KJ, Clermont PG, Fonger J, et al. One-month histologic response of transmyocardial laser channels with molecular intervention. Ann Thorac Surg 1996;62:1051-8.

7. Lin H, Parmacek MS, Morle G, Bolling S, Leiden JM. Expression of recombinant genes in myocardium in vivo after direct injection of DNA. Circulation 1990;82:2217-21.

8. Buttrick PM, Alyson K, Kitsis RN, et al. Behavior of gnes directly injected into the rat heart in vivo. Circ Res 1992;70:193-8.

9. Kaneda Y, Iwai K, Uchida T, et al. Increased expression of DNA cointroduced with nuclear protein in adult rat liver. Science 1989; 243:375-8.

10. Ascadi G, Jaio S, Jani A, et al. Direct gene transfer and expression in the rat heart in vivo. New Biol 1991;3:71-81.

11. Beck CS. The development of new blood supply to the heart by operation. Ann Surg 1935;102:801-13.

12. Vineberg A. Clinical and experimental studies in the treatment of coronary arterial insufficiency by internal mammary artery implant. J Int Coll Surg 1954;22:503-18.
13. Sen PK, Udwadia TE, Kinare SG, et al. Transmyocardial acupuncture, a new approach to myocardial revascularization. J Thorac Cardiovasc Surg 1965;50:181-9.

14. Sen PK, Daulatram J, Kinare SG, et al. Further studies in multiple transmyocardial acupuncture as a method of myocardial revascularization. Surgery 1968;64:861-70.

15. Mirhoseini M, Cayton MM. Myocardial revascularization by laser. Lasers Surg Med 1986;6:459-61.

16. Kwong KF, Kanellopoulos GK, Nickols JC, et al. Transmyocardial laser treatment denervates canine myocardium. J Thorac Cardiovasc Surg 1997;114:883-90.

17. Thomsen S. Pathologic analysis of photothermal and photomechanical effects of lasr-tissue interactions. Photochemistry 1991;53:825-35

18. Welch AJ, Motamedi M, Rastegar S, LeCarpentier GL, Jansen D. Laser thermal ablation. Photochemistry 1991;53:836-45.

18a. Sayeed-Shah U, Mann M, Zhang L, et al. Non-viral gene transfer to enhance transmyocardial laser revascularization. Surg Forum 1997;48:251-4.

19. Leung DW, Cachianes G, Kuang WJ, Goeddel DV, Ferrara N. Vascular endothelial growth factor is a secreted angiogenic mitogen. Science 1989;246:1306-9.

20. Harada K, Grossman W, Friedman M, et al. Basic fibroblast growth factor improves myocardial function in chronically ischemic porcine hearts. J Clin Invest 1994;94:623-30.

21. Banai S, Jaklitsch MT, Shou M, et al. Angiogenic-induced enhancement of collateral blood flow to ischemic myocardium by vascular endothelial growth factor in dogs. Circulation 1994;89:2183-9.

22. Nabel EG, Yang Z, Plautz G, et al. Recombinant fibroblast growth factor-1 promotes intimal hyperplasia and angiogenesis in vivo. Nature 1993;362:844-6.

23. Battler A, Scheinowitz M, Bor A, et al. Intracoronary injection of basic fibroblast growth factor enhances angiogenesis in infarcted swine myocardium. J Am Coll Cardiol 1993;22:2001-6.

24. Folkman J, Klagsburg M. Angiogenic factors. Science 1987;235: 442-7.

25. Gospodarowicz D. Fibroblast growth factor. Crit Rev Oncogene 1989;1:1-26.

26. Dzao VJ, von der Leyen HE, Morishita R. The concept and potentials of cardiovascular gene therapy. Dialog Cardiovasc Med 1997;2:3-17.

27. Kutsis R, Buttrick P, McNally E, et al. Hormonal modulation of a gene injected into rat heart in vivo. Proc Natl Acad Sci USA 1991;88:4183-42.

28. Sharma HS, Wunsch M, Brand T, et al. Molecular biology of the coronary vascular and myocardial responses to ischemia. J Cardiovasc Pharm 1992;20(suppl):523-31.

\section{Discussion}

Dr Todd Rosengart (New York, NY). At last year's AATS meeting we presented data in the same porcine ischemia model where we demonstrated complete reversal of wall motion abnormalities with the administration of an adenovirus with VEGF alone. In light of these findings, I have several questions for you. First, did you, as part of your study design, somehow handicap your VEGF therapy so you could bring out additional benefits in conjunction with TMR? If so, do you think you could further optimize your VEGF therapy 
so that you would get an improved angiogenic effect with VEGF therapy alone?

Second, do you think these data confirm the speculation that TMR works by inducting angiogenesis? If this is the case, do you think the role of TMR will eventually be as a source of inflow for angiogenic therapy or do you see another role for TMR in the future?

Dr Sayeed-Shah. In response to your first question, the genetically altered hearts treated with the plasmid encoding VEGF $_{165}$ alone did show improvement in regional contractility in focal areas within the region of reversible ischemia although this improvement was primarily seen in unstressed hearts and became inconsistent and non-uniform during rapid pacing-induced stress. These findings seem to confirm observations by others that, although myocardial collateral vessel development and blood flow seem to improve with gene therapy alone, actual functional improvement has been much more difficult to demonstrate.

It has been suggested that arteriogenesis, or the development of larger inflow vessels, may need to be stimulated before an actual functional improvement may be demonstrated. Dr Hardy has shown that the inflammatory process related to TMR application induces a prolonged monocyte infiltration. As Dr Wolfgang Schaper's work suggests, tissue responses to inflammatory stimuli that regulate monocyte activity to elaborate matrix metalloproteinases and induce fibroblast growth factor activity may be more closely related to arteriogenesis. In theory, this promotion of larger, "inflow vessels" may complement the angiogenesis mediated by VEGF, which is more typically seen in ischemic myocardium. This may, in part, explain the significantly improved function seen in the TMR-VEGF group.

There is a growing body of evidence that suggests TMR may act in the long-term by inducing a pro-angiogenic state, although other mechanisms may also be involved in producing the short-term symptomatic relief observed in patients. We chose to use a naked plasmid vehicle for these studies to mitigate the possibility of adverse tissue or immunologic responses that have been well documented by a number of groups to occur with viral vector administration, while retaining the ability to effectively transduce myocardial tissue. In addition, the relative spatial and temporal restriction on plasmid-medicated gene transfer was perceived to be beneficial in the setting of TMR because we sought to amplify a localized tissue response of recruitment of coronary microvasculature to a functionally significant level, without enhancing the potential for adverse or uncontrolled local or systemic angiogenesis.

Dr Charles R. Bridges (Philadelphia, $\mathrm{Pa}$ ). Please comment on the fact that, in your study in the TMR-alone group, you did not see an improvement in wall motion abnormalities in the TMR-alone group, which is at variance with your own statement about the fact that TMR has a salutary effect on perfusion in the absence of any additional gene therapy.

The gold standard in angiogenesis research (eg, Unger and associates) has used a similar model in both canine and porcine animal models where ameroid constrictors have been placed on the circumflex or left anterior descending artery. However, in their research, microsphere studies were used to document improvement in blood flow; in addition, it has generally been coupled with some histologic evidence of angiogenesis. Did you perform those studies? And if so, what did you find?

Dr Sayeed-Shah. In response to your first question, this discrepancy is a matter of time frame and was 1 of our primary reasons for combining these 2 treatment modalities. With TMR, the improvement in blood flow to ischemic myocardium has been demonstrated in both clinical studies and recent animal studies at 3 months and significantly so at 6 months after therapy. This implies the existence of a progressive process of revascularization that we also did not find to be significant at only 6 weeks after therapy in our animals. One potential advantage of this combined approach with TMR with gene therapy therefore would be in the acceleration of this process that we have observed in these animals at 6 weeks after therapy. Given that the stability of the proangiogenic response to gene therapy has not been determined, this addition of the observed progressive recruitment of microvasculature seen with TMR may be of further therapeutic benefit in the long term.

With respect to your second question, we are awaiting the results of the histopathologic samples collected from all the animals but do not have data to report at this time. We are currently performing a series of experiments designed to specifically evaluate regional myocardial blood flow by radioactive microspheres and by magnetic resonance imaging.

Dr Robert C. Robbins (Stanford, Calif). The functional data are impressive, but what about the transfection efficiency that you saw that was so high in the hearts with TMR. Do you have any insight into why your transfection efficiency was so much improved?

Dr Sayeed-Shah. Thermal gradients applied to cell culture lines in vitro have been shown to improve trandsuction efficiency. We have previously demonstrated that transmyocardial thermal injury may enhance gene uptake and expression in a rat model of heterotopic heart transplantation. Dr Thomsen has shown that tissue vaporization processes characteristic of infrared lasers mimic this type of injury in the myocardium with similar thermal fluence patterns. 